\title{
PENGEMBANGAN MEDIA EBOOK CERGAM BERBASIS KEARIFAN LOKAL BATIK TANJUNG BUMI UNTUK MENINGKATKAN KARAKTER SISWA
}

\author{
Kusni $^{1}$, Nasution ${ }^{2}$, Agus Suprijono ${ }^{3}$, Hendratno ${ }^{4}$ \\ Pendidikan Dasar, Pascasarjana, Universitas Negeri Surabaya ${ }^{1234}$ \\ kusni.19087@mhs.unesa.ac.id'; nasution@unesa.ac.id²; agussuprijono@unesa.ac.id ${ }^{3}$; \\ hendratno@unesa.ac.id ${ }^{4}$
}

\begin{abstract}
ABSTRAK
Penelitian ini bertujuan menghasilkan media pembelajaran untuk meningkatkan karakter sosial siswa SD. Nilai karakter berbasis kearifan lokal dari motif Batik Tanjung Bumi dikembangkan dalam media ebook cerita bergambar (selanjutnya ditulis cergam). Penelitian ini menggunakan model pengembangan 4D (define, design, develop, dan disseminate). Subjek penelitian ini adalah siswa kelas IV A sebagai kelompok eksperimen dan siswa kelas IV B sebagai kelompok kontrol di SDN Tengket 2 Kecamatan Arosbaya Kabupaten Bangkalan. Hasil penelitian ditemukan bahwa: 1.) makna dan nilai dari Batik Tanjung Bumi sesuai dengan implementasi Penguatan Pendidikan Karakter (PPK) yang dimuat dalam Permendikbud nomor 20 tahun 2018, yaitu karakter jujur, kerja keras, cinta damai, disiplin, mandiri, dan religius. 2.) media ebook cergam dinyatakan sangat layak untuk digunakan berdasarkan hasil validasi materi sebesar $91,43 \%$ dan validasi media sebesar $100 \%$. 3.) kepraktisan media ebook cergam diperoleh hasil observasi dengan skor $92 \%$ untuk uji coba perorangan, 87,5\% untuk uji coba kelompok kecil, dan $88 \%$ untuk uji lapangan dengan kategori sangat baik. 4.) hasil uji keefektifan media ebook cergam diperoleh dari pretest dan posttest pada kelompok eksperimen dan kelompok kontrol dengan nilai $\mathrm{P}$-value $(0,000)<0,05$ dan selisih nilai $\mathrm{N}$-gain score sebesar 0,27 , yakni lebih tinggi nilai $\mathrm{N}$-gain score kelompok eksperimen daripada kelompok kontrol. Dengan demikian, dapat disimpulkan bahwa penggunaan media ebook cergam yang dikembangkan dapat meningkatkan karakter sosial siswa kelas IV SDN Tengket 2 secara efektif.
\end{abstract}

Kata kunci: media ebook cerita bergambar, pendidikan karakter sosial, kearifan lokal, batik Tanjung Bumi

\begin{abstract}
This study aims to produce learning media to improve the social character of elementary school students. Character values based on local wisdom from the Tanjung Bumi Batik motif were developed in the pictorial stories ebook media. This study uses a 4D development model. (define, design, develop, and disseminate). The subjects of this study were fourth grade students $A$ as the experimental group and grade IV B students as the control group at SDN Tengket 2, Arosbaya District, Bangkalan Regency. The results of the study found that: 1.) the meaning and value of Batik Tanjung Bumi is in accordance with the implementation of 'Penguatan Pendidikan Karakter' (PPK) contained in Permendikbud number 20 of 2018, namely honest, hard work, peace-loving, disciplined, independent, and religious characters.
\end{abstract}


2.) pictorial stories ebook media is declared very feasible to use based on the results of material validation of $91.43 \%$ and media validation of $100 \%$. 3.) the practicality of the comic book media was obtained by observation with a score of $92 \%$ for individual trials, $87.5 \%$ for small group trials, and $88 \%$ for field tests with very good categories. 4.) the results of the test of the effectiveness of the pictorial stories ebook media were obtained from the pretest and posttest in the experimental group and control group with a P-value $(0.000)<0.05$ and the difference in the $N$-gain score is 0.27 , which indicates that the $\mathrm{N}$-gain score of the experimental group is higher than the N-gain score of the control group. Thus, it can be concluded that the use of the developed pictorial stories ebook media can improve the social character of the fourth grade students of SDN Tengket 2 effectively.

Keywords: pictorial stories ebook media, social character education, local wisdom, Batik Tanjung Bumi

\section{A. PENDAHULUAN}

Globalisasi menggeser nilai-nilai luhur lokal di Indonesia. Nilai budaya asing terus tumbuh dan menggerus nilai-nilai lokal bangsa. Akibatnya, karakter dan akhlak anak sebagai generasi penerus terpengaruh dan hal ini menimbulkan berbagai kasus anak berhadapan hukum $(\mathrm{ABH})$. Hal ini dapat dibuktikan berdasarkan data dari KPAI (Komisi Perlindungan Anak Indonesia), yakni ada 11.492 kasus ABH (KAI, 2019). Ditambah lagi fenomena perundungan anak baik di dunia pendidikan maupun di media sosial terus meningkat. KPAI mencatat selama kurun waktu 9 tahun, dimulai 2011 hingga 2019, terdapat 37.381 pengaduan kasus perundungan terhadap anak. Hasil survei KPAI tahun 2015 juga menunjukkan sebanyak 52\% ibu dari 800 responden keluarga sangat khawatir anaknya menjadi korban kekerasan di sekolah. Persoalan akhlak dan karakter bangsa ini apabila terus dibiarkan akan menjadi lebih kompleks hingga memicu tawuran anak sekolah dan konflik horizontal antar masyarakat. Oleh karena itu, menanamkan nilai luhur sedini mungkin di tingkat Sekolah Dasar menjadi salah satu alternatif mencegah degragasi moral bangsa.

Salah satu nilai luhur Indonesia terletak pada kearifan lokalnya. Kearifan lokal atau local genius/wisdom menurut Ayatrohaedi (1986: 30) adalah the sum of the cultural characteristics which the vast majority of a people have in common as a result of their experiences in early life. Menggali, menanamkan kembali, dan menumbuhkan kearifan lokal secara inheren ke dalam 
sistem pendidikan tampaknya adalah upaya membangun karakter dan identitas bangsa. Wisdom is considered necessary and deserves to be used as a basis for the development of education and culture (Suherman, 2021: 21). Salah satu kearifan lokal asli Indonesia adalah batik.

Batik sebagai produk kebudayaan asli Indonesia yang dikenal sejak abad ke17 ini merupakan kerajinan yang mempunyai nilai seni tinggi. Batik dikreasikan dari kain mori dengan menggunakan cairan malam serta canting dan digambar dengan berbagai motif yang diproses dengan cara tertentu (Susilaningtyas, 2020: 238). Batik banyak berkembang seiring dengan perkembangan kebudayaan (Wijayaningputri, 2020: 149). UNESCO menetapkan batik sebagai warisan kemanusiaan untuk budaya lisan dan non bendawi sejak 2 Oktober 2009 (Lisbijanto, 2013: v-vi). Satu dari sekian banyak batik yang kuat nilai-nilai karakter luhur di pulau Madura adalah Batik Tanjung Bumi. Batik Tanjung Bumi mempunyai makna dan nilai karakter sosial yang tinggi di dalamnya. Untuk itu, internalisasi pembelajaran nilai karakter dari batik Tanjung Bumi perlu diimplementasikan dalam lembaga pendidikan. Sebab menurut Sternberg (2008), sekolah dapat membantu mengembangkan kearifan. Hal ini juga dapat menghindarkan pada penyeragaman orientasi hidup masyarakat semata yang tidak sesuai konteks. Penyeragaman atas orientasi kehidupan bukan berarti ditampilkan secara transparan, tetapi diupayakan secara hegemonik (Dewojati, 2021: 168). Penguatan kearifan lokal dalam dunia pendidikan dapat menguatkan pada akar dari konteks tradisi masyarakat. Ditambah lagi menurut Maridi (2015: 31), pemberdayaan kearifan lokal dapat memunculkan adanya perubahan dasar perilaku sosial yang berhubungan dengan karakter.

Lembaga pendidikan, khususnya pendidikan formal, memiliki tugas yang sangat penting, di antaranya; mentransmisi pengetahuan, mentransmisi budaya, dan mentransmisi nilai. Oleh karena itu, lembaga pendidikan tidak hanya bertugas mentransfer ilmu semata, melainkan juga yang lebih penting membentuk karakter masyarakat (Tripayana, 2021: 138). Pendidikan karakter merupakan upaya yang dilakukan dengan tujuan mendorong tumbuh kembang 
segenap potensi manusia supaya mempunyai kepribadian dan akhlak yang mulia, serta berdampak baik terhadap masyarakat dan alam (Dewi, 2021: 35). Penerapan nilai karakter ini berada dalam segi kesosialan. Oleh karena itu, pendidikan karakter ini perlu diimplementasikan ke dalam mata pelajaran Ilmu Pengetahuan Sosial. Dengan demikian, diperlukan media pembelajaran yang memuat nilai filosofis berupa nilai karakter sosial batik Tanjung Bumi. Pendidikan karakter ini dapat dikemas melalui buku cerita bergambar, seperti Turan dan Ulutas dalam jurnalnya berjudul Using Storybooks as a Character Education Tools (2016). Namun di masa pandemi covid-19 saat ini, media pembelajaran tampaknya beralih ke ebook atau buku digital cerita bergambar (cergam) supaya lebih mudah diakses dan sesuai dengan kondisi pembelajaran daring.

Berdasarkan uraian di atas, penelitian ini berupaya mengembangkan media ebook cergam (cerita bergambar) berbasis kearifan lokal Batik Tanjung Bumi untuk meningkatkan karakter sosial siswa SD, maka dirumusankan pertanyaan penelitian sebagai berikut: Apa saja makna dan nilai yang terkandung di dalam motif batik Tanjung Bumi? Bagaimana kelayakan media ebook cergam berbasis kearifan lokal batik Tanjung Bumi yang dikembangkan? Bagaimana kepraktisan media ebook cergam yang dikembangkan? Bagaimana keefektifan media ebook cergam ini dalam meningkatkan karakter sosial siswa SD?

\section{B. METODE PENELITIAN}

Model penelitian ini adalah penelitian dan pengembangan (research and development). Menurut Sugiono (2017: 407), jenis penelitian $R \& D$ ini digunakan untuk menghasilkan produk tertentu sekaligus menguji keefektifan produk tersebut. Jenis penelitian ini dimulai dengan penelitian atau observasi lapangan untuk memperoleh gambaran persoalan yang ada di dalam proses pembelajaran siswa dan dilanjutkan dengan pengembangan untuk menghasilkan produk baru untuk mengatasi persoalan tersebut. Produk yang didesain dari penelitian ini adalah ebook cergam mata pelajaran Ilmu Pengetahuan Sosial. Research and development ini dilakukan dalam siklus 4-D Thiagarajan, dkk (1974: 5), yakni Define, Design, Develop, dan Disseminate. 
Pada tahap define, dilaksanakan dengan analisis kebutuhan, analisis peserta didik, analisis tugas pembelajaran dan analisis konsep untuk menentukan syarat pembelajaran. Dalam tahap design dilakukan penyusunan instrumen, pemilihan media, format dan penyusunan rancangan awal. Selanjutnya, pada tahap develop, rancangan awal ebook cergam yang dikembangkan diberikan kepada ahli media dan ahli materi untuk dinilai berdasarkan angket yang telah diserahkan.

Kemudian, produk diujicobakan ke satu per satu siswa untuk memahami nilai karakter yang dipunyai siswa SDN Tengket 2 Kecamatan Arosbaya Kabupaten Bangkalan. Dalam hal ini, 3 peserta didik yang mewakili terdiri dari anak berkemampuan tinggi, berkemampuan sedang dan rendah. Lalu, draft ebook cergam direvisi dan didapatkan draft 2 ebook cergam untuk diujicobakan ke kelompok kecil. Setelah ada masukan dari responden, draft 2 direvisi menjadi draft 3 ebook cergam untuk diujikan lapangan kepada siswa kelas IV A dan siswa kelas IV B SDN Tengket 2 yang masing-masing berjumlah 21 siswa. Akhirnya pada tahap pengembangan dilakukan post test untuk menguji keefektifan dan kepraktisan media pembelajaran ebook cergam yang dikembangkan.

Subjek penelitian dalam penelitian ini adalah siswa kelas IV A dan siswa kelas IV B SDN Tengket 2 Kecamatan Arosbaya Kabupaten Bangkalan yang berusia antara 9-11 tahun. Dalam hal ini, siswa kelas IV A sebagai kelompok eksperimen, sementara siswa kelas IV B sebagai kelompok kontrol. Instrumen pengumpulan data dalam penelitian ini adalah lembar validasi media pembelajaran untuk ahli media, lembar validasi untuk ahli materi, lembar angket respon siswa, dan lembar penilaian pembelajaran. Data penelitian berupa data deskriptif kuantitatif dari hasil penilaian validasi ahli materi dan ahli media untuk menilai kelayakan produk ebook cergam, hasil respon peserta didik untuk menilai kepraktisan, dan hasil belajar peserta didik untuk menilai keefektifan pembelajaran menggunakan ebook cergam yang dikembangkan. 
Teknik analisis data penelitian ini dilakukan dengan cara: pertama, mengkonversikan data validasi dari ahli materi dan ahli media menjadi skor berupa angka untuk dihitung presentase kelayakan ebook cergam yang dikembangkan. Setelah dinyatakan layak, analisis keefektifan produk ebook cergam dilakukan dari hasil tes siswa berupa prestest dan post test pada kelompok eksperimen dan kelompok kontrol. Dengan analisis N-gain, keefektifan ebook cergam didapatkan. Angka skor dari angket respon siswa dihitung untuk mendapatkan presentase kepraktisan ebook cergam.

\section{HASIL DAN PEMBAHASAN}

Penelitian ini bertujuan menghasilkan produk media pembelajaran ebook cergam berbasis kearifan lokal Batik Tanjung Bumi untuk meningkatkan karakter sosial siswa SDN Tengket 2 Kecamatan Arosbaya Kabupaten Bangkalan. Oleh karena itu, berikut ini gambaran hasil media ebook cergam yang dikembangkan.

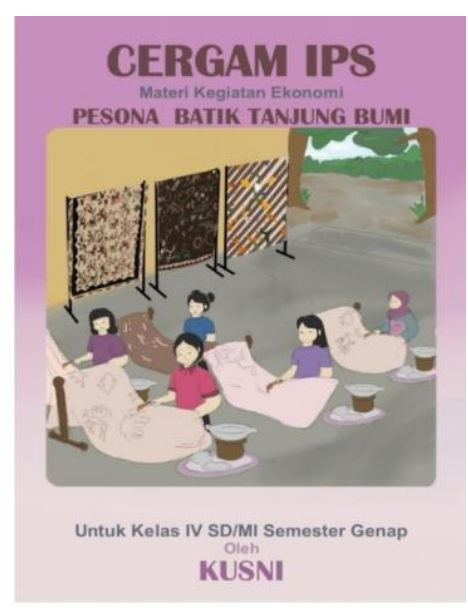

Gambar 1.1

Cover Depan Ebook Cergam

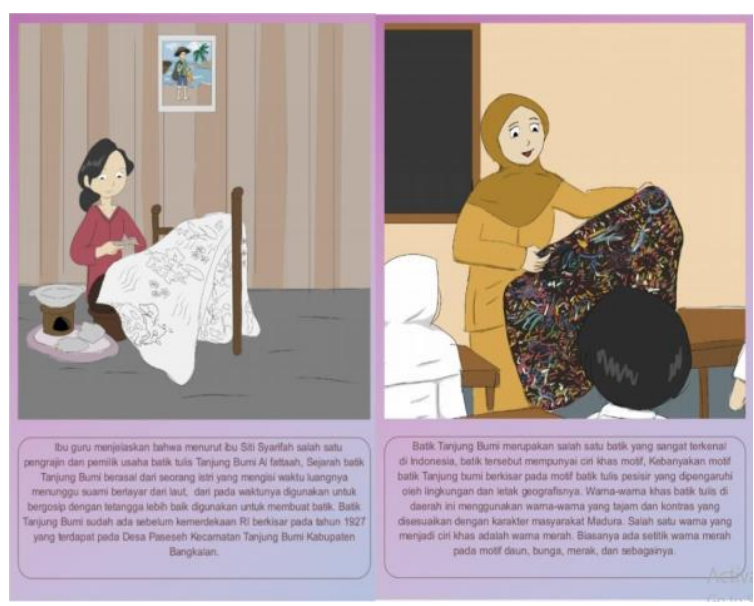

Gambar 1.2

Bagian Isi Media Ebook Cergam

Makna dan nilai dari motif Batik Tanjung Bumi diterangkan untuk memperoleh makna dan nilai karakter sosial dari Batik Tanjung Bumi. Hasil validasi kelayakan media ebook cergam tersebut dilihat dari penilaian segi materi dan segi media. Sedangkan kepraktisan ebook cergam didapatkan dari respon siswa di kelompok eksperimen melalui uji coba perorangan, uji coba kelompok kecil, dan uji lapangan. Untuk keefektifan dari media ebook cergam 
diambil dari hasil pretest dan posttest pada kelompok eksperimen dan kelompok kontrol. Berikut ini pembahasan secara lebih detail.

\section{Makna dan Nilai Motif Batik Tanjung Bumi}

Berdasarkan hasil wawancara dengan pemilik dan pengrajin batik Tanjung Bumi bernama ibu Siti Syarifah diketahui bahwa sejarah batik ini berasal dari seorang istri yang mengisi waktu luangnya menunggu suami datang melaut. Daripada waktunya digunakan untuk bergosip, seorang istri ini membuat batik Tanjung Bumi dengan berbagai macam motif, makna dan nilai filosofis yang terkandung di dalamnya. Berikut ini motif, makna simbolik dan nilai dari batik Tanjung Bumi.

Tabel 1. Makna dan Nilai Motif Batik Tanjung Bumi

\begin{tabular}{|l|l|l|}
\hline \multicolumn{1}{|c|}{ Motif } & \multicolumn{1}{c|}{ Makna Simbolik } & \multicolumn{1}{c|}{ Nilai } \\
\hline Carcenah & Bulatan kecil lambang keutuhan dan keindahan & Keindahan \\
\hline $\begin{array}{l}\text { Tasik } \\
\text { Malaya }\end{array}$ & Gelombang laut dan bunga lambang kesetiaan & Kesetiaan \\
\hline Leres & Garis lurus sejajar lambang kejujuran & Jujur \\
\hline Lak-olak & $\begin{array}{l}\text { Kumpulan ulat memakan pohon lambang kerja } \\
\text { keras kehidupan }\end{array}$ & Kerja Keras \\
\hline Manohara & Sepasang burung berhadapan simbol cinta kasih & $\begin{array}{l}\text { Cinta } \\
\text { Damai }\end{array}$ \\
\hline Perkutut & $\begin{array}{l}\text { Burung perkutut simbol kegagahan dan } \\
\text { ketampanan }\end{array}$ & Kesetiaan \\
\hline Gentongan & $\begin{array}{l}\text { Kumpulan dari berbagai motif batik Tanjung } \\
\text { Bumi simbol ketepatan waktu }\end{array}$ & Disiplin \\
\hline Kembheng & Kumpulan bunga di taman lambang keindahan & Keindahan \\
\hline Malathe & Bunga melati lambang keindahan & Keindahan \\
\hline $\begin{array}{l}\text { Gajah } \\
\text { Cantik }\end{array}$ & Gajah berdiri tegak lambang kemandirian & Mandiri \\
\hline Pal kapal & $\begin{array}{l}\text { Perahu kyai mencari ikan sambil berdakwah } \\
\text { sinbol pelajaran agama }\end{array}$ & $\begin{array}{l}\text { Nilai } \\
\text { Religius }\end{array}$ \\
\hline
\end{tabular}

Berdasarkan makna dan nilai simbolik dari motif Batik Tanjung Bumi mengandung nilai-nilai karakter, yaitu religius, kerja keras, disiplin, cinta damai, jujur dan mandiri. Nilai-nilai ini sesuai dengan Penguatan Pendidikan Karakter (PPK) yang terdapat dalam Permendikbud nomor 20 tahun 2018 tentang PPK pada satuan pendidikan formal. 
Nilai karakter berkelindan dengan persoalan sosial, sehingga mata pelajaran yang dipilih untuk implementasi nilai-nilai karakter dalam batik Tanjung Bumi adalah mata pelajaran Ilmu Pengetahuan Sosial (IPS). Nilai kearifan lokal harus dimanfaatkan untuk memperkaya sumber materi yang telah dikembangkan (Setiawan, 2020: 131). Hal ini supaya nilai-nilai karakter yang terkandung dapat meningkatkan kesosialan siswa.

Materi dalam media ebook cergam ini disusun untuk memenuhi kriteria Kompetensi Inti 3 (KI 3), Kompetensi Dasar (KD), dan Indikator Pencapaian Pembelajaran. Rinciannya, Kompetensi Inti dirumuskan untuk memberi pemahaman faktual dalam kehidupan sosial dengan melalui refleksi nilai-nilai motif Batik Tanjung Bumi. Kompetensi Dasar (KD) dirumuskan untuk mencapai korelasi antara makna dan identifikasi materi Ilmu Pengetahuan Sosial sehingga menarik dan memunculkan antusiasmi dari para siswa kelas IV SD. Sementara Indikator Pencapaian Pembelajaran diarahkan pada pembentukan sekaligus penguatan akhlak dan karakter peserta didik sesuai KI dan KD.

\section{Kelayakan Ebook Cergam}

Hasil validasi kelayakan ebook cergam didapatkan dari penilaian segi materi dan media. Validator materi dalam penelitian ini adalah Dr. Waspodo Tjipto Subroto, M.Si, sedangkan validator media adalah Dr. Fajar Arianto, S.Pd., M.Pd. Berikut ini hasil validasi dari kedua validator.

Tabel 2. Rekapitulasi Hasil Validasi Ahli Materi

\begin{tabular}{|l|c|}
\hline \multicolumn{1}{|c|}{ Aspek } & Skor \\
\hline Identitas Pembelajaran & 5 \\
\hline Kompetensi Inti (KI) & 5 \\
\hline Kompetensi dasar (KD) & 5 \\
\hline Indikator Pencapaian & 4 \\
\hline Indikator pencapaian & 4 \\
\hline Kebutuhan bahan ajar & 5 \\
\hline
\end{tabular}




\begin{tabular}{|l|c|}
\hline Pencapaian nilai karakter & 4 \\
\hline Skor total & $\mathbf{3 2}$ \\
\hline Presentase & $\mathbf{9 1 , 4 3 \%}$ \\
\cline { 2 - 2 } & Sangat Valid \\
\hline
\end{tabular}

Berdasarkan tabel hasil validasi ahli materi di atas diketahui bahwa validasi kelayakan materi ebook cergam mendapatkan total skor sebesar 32 dari skor maksimal 35. Dengan demikian, skor rata-rata diperoleh sebesar 4,57 dengan presentase sebesar $91,43 \%$.

Tabel 3. Rekapitulasi Validasi Materi

\begin{tabular}{|c|c|l|}
\hline Rata-rata & Penilaian & \multicolumn{1}{|c|}{ Keterangan } \\
\hline 4,57 & $91,43 \%$ & Sangat Layak \\
\hline
\end{tabular}

Nilai rata-rata dan presentase hasil validasi kelayakan materi ebook cergam pada tabel 3. di atas menunjukkan bahwa ebook cergam yang dikembangkan sangat valid dan layak digunakan. Sementara hasil validasi media dari Dr. Fajar Arianto, S.Pd., M.Pd, dalam hal ini selaku ahli media, didapatkan hasil sebagai berikut.

Tabel 4. Hasil Validasi Ahli Media

\begin{tabular}{|l|c|}
\hline \multicolumn{1}{|c|}{ Aspek } & Skor \\
\hline Kejelasan materi Pembelajaran & 5 \\
\hline Kesesuaian ilustrasi dengan materi & 5 \\
\hline Kesesuaian aplikasi dengan konsep materi & 5 \\
\hline Kesesuaian penguatan penilaian karakter pada materi & 5 \\
\hline Kesesuaian bahasa dengan kemampuan peserta didik & 5 \\
\hline Kemudahan memahami bahasa yang dipakai & 5 \\
\hline
\end{tabular}




\begin{tabular}{|l|c|}
\hline Ketetapan penulisan ejaan dan tanda baca & 5 \\
\hline Ukuran Gambar dan ilustrasi & 5 \\
\hline Keseimbangan proporsi gambar, ilustrasi, dan teks & 5 \\
\hline Ketetapan Letak Alur Cerita & 5 \\
\hline Kejelasan Alur Cerita & 5 \\
\hline Ketetapan pemilihan karakter tokoh & 5 \\
\hline Kesesuaian gambar dengan cerita & 5 \\
\hline Ketetapan pemilihan jenis dan ukuran huruf & 5 \\
\hline Kesesuaian gambar, animasi, dan ilustrasidengan cerita & $\mathbf{7 5}$ \\
\hline Skor total & $\mathbf{1 0 0 \%}$ \\
\hline Presentase & Sangat Valid \\
\hline
\end{tabular}

Berdasarkan tabel 4. tersebut tampak bahwa total skor hasil validasi media diperoleh skor sebesar 75 dari skor maksimal 75. Hal ini menunjukkan bahwa validasi media ebook cergam mendapatkan skor sempurna dan rata-ratanya sebesar 5. Presentase hasil validasi media di atas diperoleh sebesar 100\%.

Tabel 5. Rekapitulasi Validasi Media

\begin{tabular}{|c|c|c|}
\hline Rata-rata & Penilaian & Keterangan \\
\hline 5 & $100 \%$ & Sangat Layak \\
\hline
\end{tabular}

Skor rata-rata dan presentase kelayakan media ebook cergam yang dikembangkan di atas dapat ditarik kesimpulan bahwa media ebook cergam sangat valid dan layak untuk digunakan. 
Aspek teknis penggunaan media ebook cergam berbasis kearifan lokal motif batik Tanjung Bumi ini berdasarkan pelaksanaan pembelajaran di kelas IV A SDN Tengket 2 diketahui melalui observasi. Kelas IV A dipilih karena diperlakukan sebagai kelompok eksperiman yang mana proses pembelajarannya menggunakan media ebook cergam, bukan media konvensional. Berikut ini hasil rekapitulasi obervasi pembelajaran.

Tabel 6. Rekapitulasi Observasi Pembelajaran

\begin{tabular}{|l|c|c|l|}
\hline Jenis Obervasi & Rata-rata skor & Presentase & Keterangan \\
\hline $\begin{array}{l}\text { Kegiatan } \\
\text { Pembelajaran }\end{array}$ & 42,56 & $89 \%$ & Sangat Baik \\
\hline Aktivitas Siswa & 34,96 & $87,4 \%$ & Sangat Baik \\
\hline
\end{tabular}

Berdasarkan tabel 6. tentang rekapitulasi hasil observasi pembelajaran menggunakan media ebook cergam yang dikembangkan, kegiatan pembelajaran mendapat skor rata-rata sebesar 42,56 dengan presentase $89 \%$, dan aktivitas siswa memperoleh skor rata-rata 34,96 dengan presentase sebesar $87,4 \%$. Hasil ini menunjukkan bahwa secara keseluruhan kegiatan pembelajaran dan aktivitas siswa berkategori sangat baik.

\section{Kepraktisan Ebook Cergam}

Kepraktisan media ebook cergam diketahui dari respon siswa melalui beberapa uji coba, yakni uji coba perorangan (one to one), uji coba kelompok kecil berisi 3 siswa, dan uji lapangan kepada 21 siswa kelompok eksperimen. Angket respon siswa diberikan melalui aplikasi whatapp grup kelas dan siswa diminta untuk mengumpulkan jawaban dari angket tersebut melalui whatapp pribadi guru. Adapun angket berisi 5 butir pertanyaan, yaitu kemenarikan gambar, kemudahan bahasa, kemudahan memahami alur cerita, kemudahan mengunduh, dan kemudahan menggunakan media ebook cergam. Berikut ini rekapitulasi hasil respon siswa.

Tabel 7. Rekapitulasi Hasil Kepraktisan Media Ebook Cergam 


\begin{tabular}{|l|c|c|l|}
\hline \multicolumn{1}{|c|}{ Jenis uji coba } & $\begin{array}{c}\text { Rata- } \\
\text { rata skor }\end{array}$ & Presentase & \multicolumn{1}{|c|}{ Kriteria } \\
\hline Uji coba one to one & 23 & $92 \%$ & Sangat Baik \\
\hline Uji coba kelompok kecil & 21,89 & $87,5 \%$ & Sangat Baik \\
\hline Uji lapangan & 22 & $88 \%$ & Sangat Baik \\
\hline
\end{tabular}

Hasil Respon dari siswa pada uji coba one to one dilakukan kepada 3 siswa yang dipilih secara random dari kelompok eksperimen. Dari 5 butir pertanyaan, rata-rata skor total diperoleh 23 dengan presentase $92 \%$.

Sementara uji coba kelompok kecil dilakukan kepada 9 siswa yang masing-masing 3 siswa mewakili siswa berkemampuan tinggi, 3 siswa berkemampuan sedang, dan 3 siswa berkemampuan rendah berdasarkan pretest. Uji coba kelompok kecil mendapatkan hasil rata-rata skor total sebesar 21,89 dengan presentase $87,5 \%$.

Uji lapangan terhadap media ebook cergam sendiri diterapkan kepada seluruh siswa kelas IV A SDN Tengket 2 yang berjumlah 21 siswa dan diperlakukan sebagai kelompok eksperimen. Uji lapangan ini diperoleh rata-rata skor 22 dengan presentase $88 \%$. Dari ketiga uji coba yang dilaksanakan untuk mengukur kepraktisan media ebook cergam yang dikembangkan bisa disimpulkan bahwa media ebook cergam adalah sangat praktis dan baik untuk digunakan.

\section{Keefektifan Ebook Cergam}

Untuk menghitung keefektifan media ebook cergam berbasis kearifan lokal batik Tanjung Bumi yang dikembangkan, uji independent sample $\mathrm{t}$ test untuk mencari n-gain score perlu ditemukan. Data didapatkan dari hasil pretest dan posttest baik pada kelompok eksperimen maupun kelompok kontrol. Lembar angket soal pretest dan post test diberikan melalui whatsapp group, jawabannya difoto dan dikumpulkan melalui whatsapp pribadi guru. Setelah hasil pretest didapatkan, kemudian kelas IV A sebagai kelompok eksperimen diberikan perlakuan memakai ebook cergam, sedangkan kelas IV B sebagai kelompok 
kontrol menggunakan pembelajaran konvensional. Setelah itu, posttest dilaksanakan.

Adapun syarat untuk uji independent sample t test dalam penelitian, uji normalitas dan uji homogenitas harus dilakukan. Di saat data berdistribusi normal dan homogen, uji independent sample t test dilaksanakan. Berikut ini tabel hasil uji normalitas data pretest dan data posttest kelompok eksperimen dan kelompok kontrol.

Tabel 8. Uji Normalitas

\begin{tabular}{|c|c|c|c|}
\hline & Data & Sig. & Distribusi Data \\
\hline $\begin{array}{c}\text { Kelompok } \\
\text { Eksperimen }\end{array}$ & Pretest & 0,200 & Normal \\
\cline { 2 - 4 } & Posttest & 0,080 & Normal \\
\hline \multirow{2}{*}{$\begin{array}{c}\text { Kelompok } \\
\text { Kontrol }\end{array}$} & Pretest & 0,200 & Normal \\
\cline { 2 - 4 } & Posttest & 0,070 & Normal \\
\hline
\end{tabular}

Adapun cara melihat data berdistribusi normal atau tidak adalah dengan menghitung nilai P-value. Apabila nilai P-value > 0,05, maka data berdistribusi normal. Berdasarkan tabel di atas, semua data pretest dan posttest dari kelompok eksperimen maupun kelompok kontrol diperoleh nilai P-value lebih besar daripada nilai taraf signifikan $(0,05)$. Oleh karena itu, semua data berdistribusi normal. Langkah selanjutnya adalah uji homogenitas n-gain score sebagaimana berikut.

Tabel 9. Uji Homogenitas N-gain Score

\begin{tabular}{|c|c|c|c|}
\hline \multirow{2}{*}{ Kelompok } & \multicolumn{2}{|c|}{$\begin{array}{c}\text { Levene's Test for Equality } \\
\text { of Variances }\end{array}$} & Keterangan \\
\cline { 2 - 3 } & F & P-Value & \\
\hline $\begin{array}{l}\text { Eskperimen } \\
\text { dan Kontrol }\end{array}$ & 0,084 & 0,773 & Homogen \\
\hline
\end{tabular}

Data dianggap homogen ketika nilai P-value > 0,05 atau lebih besar daripada nilai taraf signifikan. Berdasarkan nilai P-value di dalam tabel tersebut, 
tampak bahwa nilai P-value sebesar 0,773. Artinya, nilai P-value 0,773>0,05. Dengan demikian, data pretest dan posttest baik kelompok eksperimen maupun kelompok kontrol dinyatakan homogen.

Berdasarkan syarat uji t data tidak berpasangan (independent sample t-test) bahwa data berdistribusi normal dan variasi homogen, maka uji t n-gain score dapat dilakukan. Berikut ini hasil penghitungan nilai n-gain score kelompok eksperimen dan kelompok kontrol.

Tabel 10. Uji Perbedaan N-gain Kelompok Eksperimen dan Kelompok Kontrol

\begin{tabular}{|c|c|c|c|}
\hline Kelompok & N-gain & t & P-value \\
\hline Eksperimen dan Kontrol & 0,27 & 4,569 & 0,000 \\
\hline
\end{tabular}

Tabel di atas menunjukkan perbedaan N-gain score hasil pengembangan media ebook cergam berbasis kearifan lokal Batik Tanjung Bumi pada kelompok eksperimen dan kelompok kontrol yakni dengan nilai P-value sebesar 0,000. Dari hasil nilai p-value tersebut berarti 0,000 $<0,05$ (nilai P-value lebih kecil daripada taraf signifikan), sehingga dapat ditarik kesimpulan bahwa terdapat perbedaan signifikan antara N-gain score hasil di kedua kelompok tersebut. Selisih antara N-gain score kelompok eksperimen dan kelompok kontrol sebesar 0,27 dengan nilai $\mathrm{N}$-gain score kelompok eksperimen lebih tinggi daripada nilai N-gain score kelompok kontrol. Dengan demikian, nilai $\mathrm{N}$-gain score yang tinggi pada kelompok eksperimen menunjukkan bahwa perlakuan berupa penggunaan media ebook cergam berbasis kearifan lokal Batik Tanjung Bumi yang dikembangkan berhasil memberikan peningkatan sangat efektif terhadap nilai karakter sosial siswa.

\section{KESIMPULAN}

Berdasarkan hasil dan pembahasan di atas, kesimpulan yang dapat diambil adalah bahwa penelitian ini menghasilkan produk media pembelajaran ebook cergam berbasis kearifan lokal Batik Tanjung Bumi yang diterapkan kepada siswa kelas IV SDN Tengket 2 dengan materi pelajaran Ilmu Pengetahuan Sosial. 
Makna dan simbol motif batik Tanjung Bumi mempunyai nilai karakter yang sesuai dengan implementasi PPK (Penguatan Pendidikan Karakter)yang termuat dalam Permendikbud nomor 20 tahun 2018. Jujur, kerja keras, cinta damai, disiplin, mandiri, dan religius adalah nilai-nilai yang ada didalamnya. Implementasi nilai-nilai karakter ini terkait erat dengan kondisi sosial budaya masyarakat setempat dalam pelajaran IPS. Dengan demikian, nilai-nilai karakter dalam batik Tanjung Bumi dapat menumbuhkan kesosialan siswa yang perlu disampaikan melalui media pembelajaran yang menarik, dalam hal ini media ebook cergam.

Hasil validasi kelayakan media ebook cergam diperoleh presentase 91,48\% untuk materi dan $100 \%$ untuk media. Hal ini menunjukkan bahwa media ebook cergam yang dikembangkan sangat layak untuk digunakan. Untuk uji kepraktisan, media ebook cergam memperoleh nilai $92 \%$ untuk uji coba perorangan, 87,5\% untuk uji coba kelompok kecil, dan $88 \%$ untuk uji lapangan, sehingga dapat dimengerti ebook cergam berkategori baik.

Keefektifan media ebook cergam yang dikembangkan diketahui dari perbedaan $\mathrm{N}$-gain score pada kelompok eksperimen dan kelompok kontrol. Hasilnya adalah ditemukan nilai P-value sebesar $0,000<0,05$. Hal ini menunjukkan terdapat perbedaan sigfinikan antara $\mathrm{N}$-gain score dengan diterapkannya kepada kelompok eksperimen. Kemudian, nilai $\mathrm{N}$-gain score kelompok eksperimen lebih tinggi dibandingkan nilai $\mathrm{N}$-gain score kelompok kontrol, yakni dengan selisih 0,27. Dengan demikian, dapat disimpulkan bahwa penggunaan media ebook cergam berbasis kearifan lokal Batik Tanjung Bumi memberikan efek sangat efektif dalam meningkatkan nilai karakter sosial siswa.

Sedangkan kekurangan media ebook cergam ini adalah ukurannya terlalu kecil untuk ditunjukkan ke kelas besar, kurang efektif dalam pembelajaran kompleks, dan cenderung menekankan persepsi indrawi semata. Saran penelitian lebih lanjut adalah para peneliti dapat mengembangkan model pembelajaran dari 
kearifan lokal daerah masing-masing sehingga dapat dikemas sebagai sumber belajar di sekolah.

\section{REFERENSI}

Ayatrohaedi. 1986. Kepribadian Budaya Bangsa (Local Genius). Jakarta: Pustaka Pelajar.

Dewi, R R., Suresman, E., \& Suabuana, C. 2021. Pendidikan Karakter Mandiri Melalui Blended Learning di Sekolah Menengah Pertama. Jurnal Edueksos: The Journal of Social and Economic Education, 10(1), pp. 32-47.

Dewojati, C., \& Arifin, M. Z. 2021. Biopolitik dan Krisis Kedaulatan dalam Novel Lampuki Karya Arafat Nur. Jurnal Pengajian Melayu (JOMAS), 32(1), pp. 156-175. Retrieved from https://ajap.um.edu.my/index.php/JPM/article/view/29661

Hamidin, A S. 2010. Batik Warisan Budaya Asli Indonesia. Yogyakarta: Narasi.

Joyce, B., Weil, M., \& Calhoun, E. 2009. Models of Teaching: Model-model Pengajaran. Yogyakarta: Pustaka Pelajar.

KAI. 2019. Anak Berhadapan Hukum Tertinggi, Potret Buram Perlindungan Anak. https://www.kai.or.id/berita/15871/anak-berhadapan-hukum-tertinggi-potretburam-perlindungan-anak.html. Diakses tanggal 11 Januari 2021.

Kirschenbaum, Howard. 2000. From Values Clarification to Character Education. The Journal of humanistic counseling, education and development, 39(1), pp. 4-20. https://doi.org/10.1002/j.2164-490X.2000.tb00088.x

Lickona. 2013. Mendidik untuk Membentuk Karakter. Bandung: Bumi Aksara.

Lisbijanto, H. 2013. Batik. Yogyakarta: Graha Ilmu.

Mauludi, S. 2020. Socrates Cafe-Bijak, Kritis \& Inspiratif Seputar Dunia \& Masyarakat Digital. Jakarta: Elex Media Komputindo.

Maridi. 2015. Mengangkat Budaya dan Kearifan Lokal dalam Sistem Konservasi Tanah dan Air. Seminar Nasional XII Pendidikan Biologi FKIP UNS. 2015. 20-39.

Musman, A. 2011. Batik: Warisan Adiluhung Nusantara. Yogyakarta: G-Media.

Nahar, N I. 2016. Penerapan Teori Belajar Behavioristik dalam Proses Pembelajaran. Nusantara: Jurnal Ilmu Pengetahuan Sosial, 1(1), pp. 64-74.

Permendikbud. 2018. Peraturan Menteri Pendidikan dan Kebudayaan Republik Indonesia Nomor 20 Tahun 2018 Tentang Penguatan Pendidikan Karakter pada Satuan Pendidikan Formal. https://jdih.kemdikbud.go.id/arsip/Permendikbud_Tahun2018_Nomor20.pdf diakses tanggal 12 Januari 2021. 
Rachmadyanti, P. 2017. Penguatan Pendidikan Karakter bagi Siswa Sekolah Dasar melalui Kearifan Lokal. Jurnal Pendidikan Sekolah Dasar, 3(2), pp. 201-214. http://dx.doi.org/10.30870/jpsd.v3i2.2140

Sarkawi, D. 2016. Perubahan Sosial dan Budaya Akibat Media Sosial. Jurnal Administrasi Kantor, 4(2), pp. 307-338.

Setiawan, I., \& Mulyati, S. 2020. Pembelajaran IPS Berbasis Kearifan Lokal. Jurnal Ilmiah Pendidikan Dasar, 7(1), pp. 121-133.

Sugiono. 2015. Metode Penelitian Kuantitatif, Kualitatif, dan R\&D. Bandung: Alfabeta.

Suherman, A. 2021. Development of Social Education Learning Materials Based on Local Wisdom. Jurnal Edueksos: The Journal of Social and Economic Education, 10(1), pp. 20-31.

Sternberg, R J., Jarvin., \& Linda. 2008. Teaching for Wisdom Through History: Infusing Wise Thinking Skills in School Curriculum. Netherland: Springer.

Suryanti, S., Mariana, N., Yermiandhoko, Y., \& Widodo, W. 2020. Local WisdomBased Teaching Material for Enhancing Primary Students' Scientific Literary Skill. Jurnal Prima Edukasia, 8(1), pp. 96-105.

Susilaningtyas, Y., Suprijono, A., \& Jacky, M. 2020. Makna Simbolik dan Nilai-nilai Motif pada Motif Batik Jetis: Kajian Etnopedagogik Budaya Lokal untuk Penguatan Pendidikan Karakter Bangsa Siswa Kelas IV SD. Jurnal Education and Development, 8(3), pp 237-241.

Thiagarajan, S., Semmel, D.S., \& Semmel, M.I. 1974. Instructional Development for Training Teachers of Exceptional Children a Source Book. Indiana: ERIC.

Thresia, F. 2015. Integrating Local Culture to Promote Character Education in Teaching Writing. Premise Journal, 4(1).

Tripayana, I N A., Mufidah, N., Handayani, N., \& Basyariah. 2021. Internalisasi Nilai-nilai Pendidikan Karakter pada Tradisi Magibung. Jurnal Edueksos: The Journal of Social and Economic Education, 10(1), pp. 135-148.

Turan, F., \& Ulutas, I. 2016. Using Storybooks as a Character Education Tools. Journal of Education and Practice, 7(15), pp. 169-176.

Wijayaningputri, A R., \& Regina, B D. 2020. Visualisasi dan Makna Filosofi Motif Batik Teratai di Galeri Soendari Berbasis Penguatan Pendidikan Karakter. Jurnal Pemikiran dan Pengembangan Sekolah Dasar (JP2SD), 8(2), pp 148156. https://doi.org/10.22219/jp2sd.v8i2.13813 